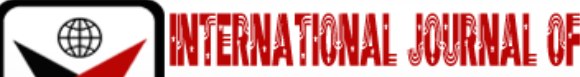

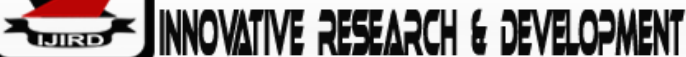

ISSN 2278-0211 (Online)

\section{Impact of Multinational Corporation on Economic Growth in Nigeria}

\author{
Qamar Muhammad Usamah \\ Manager, Najma Memorial School, Sokoto, Nigeria \\ Dr. Mairo Abdullahi \\ Senior Lecturer, Department of Business, \\ UsmanuDanfodiyo University,Sokoto, Nigeria
}

\begin{abstract}
:
The impact of the multinational corporation in oil sector has been observed through this study. The study employs secondary data attained from the Central Bank of Nigeria (CBN) Statistical Bulletin and National Office for Technology Acquisition and Promotion (NOTAP). It employs the unit root test and granger causality techniques as the econometric tools of analysis. The Augmented Dickey Fuller (ADF) unit root test results show that all the variables were stationary. The granger causality test results demonstrated that the MNCs in oil and agricultural sectors does have impact on economic growth in Nigeria. Based on these findings, the study recommends amongst others that there is the need for government to create a convenient environment for moremultinational firms to come in to both oil and agricultural sectors in order to gain the advantage of technology transfer to Nigeria. This will in turn enhancement the development process of the economy and also, the need to acclimatize and indigenize the technology that cannot be over emphasized.
\end{abstract}

Keywords: Multinational, corporation, economic growth, service sector, and causality

\section{Introduction}

Nigerian as a developing country has played host to MNCs prior independence till date. Although it has many corporations but still it struggles for socio-economic development (Onudogo, 2013). Nigerian Multinational Corporations mostly evolve after the abolition of slave trade (Aworom, 2013). Technological advancement has caused Nigeria as one of the apparent targets. Multinational corporation like Leventis, the United African Company (UAC), Coca-Cola, Lever Brother, Nestle, Stanbic IBTC, DHL, IBM, MAERSK, Unilever, MobilOil, Shell BP,Etisalat, Julius Berger, Cadbury, P\&G,PZ, GlaxoSmithKline present in the Nigerian economy. Moreover, Multinational Corporations are known to impact on the world economy. For instance, the presence of foreign investments in China, Korea and Singapore, have helped in no small measure to boost the economy of these countries by increasing their general income level and stimulate domestic production. But the reverse is the case in Nigeria. This made most economic expert to believe that the multinational companies are exploitive as the natural resources found in their host countries such as Nigeria (Osuagwu and Ezie, 2013). Elukka, Ndubuisi and Anekwe (2016) highlighted the cessations and leakages caused Nigeria lost $\$ 2.46$ Trillion in 2006, \$2.69 Trillion in 2007 and $\$ 2.97$ Trillion in 2008. From the above background the study tries to find the contribution of Multinational Corporation to Nigerian economic growth.

\section{Literature Review}

\subsection{Theoretical Literature}

Tejvanne (2013) proposed the new trade theory. The theory communicates critical factors in determining international trade patterns. These economies of scale and network of effects are very significant drivers. Economies of scale is fundamental to Henry ford's assembly line. New Trade theory explains the growth of globalization. This theory promotes the role of the government for supporting the growth of the vital industries.

Empirically, Osuagwu and Ezie (2013) examined Multinational Corporations and the Nigerian economy. Specifically, it analyses how MNCs has served as agents of imperialism in any economy where they operate. Most economist believe that the MNCs are exploitative of natural resources found in developing nations which are not effectively utilized due to de-capitalization of the economy in form of profit deportation. It argues however that in spite of the negative activities of MNCs however, they contribute positively in the areas of technology development and creation of employment opportunities.

Eluka, Ndubusi and Anekwe (2016) examined the effect of multinational corporations on the Nigerian economy. The study utilized content analysis of library materials. Findings have revealed that MNCshave not done well to the 
Nigeria economy in terms of profit repatriation, environmental degradation, bribery and corruption. Udensi (2015) examined the Multinational Corporation and economic development in Nigeria. The study analysed how MNCs has served as agents of imperialism in any economy where they contribute positively in the areas of technology development and job creation.

The study employed the use of articles, scholarly journals and textbooks to analysis the activities of multinational firms in relation to Nigeria's economic development. From the exploratory literature, the study discovered that multinational corporation have contributed to the economic development of Nigeria, though varies, the extent of technology internalization and transfers still remains a mirage. Okon, Augustine and Chuku (2012) examined the relationship between Foreign Direct Investment (FDI) and economic growth in Nigeria.

\section{Methodology}

This study mainly employs secondary data relating to the dependent and independent variable, from 1985 to 2015. The data was source from central bank of Nigeria statistical bulletin and national office for Technology Acquisition and Promotion (NOTAP). The study used ADF test granger causality test. The augmented dickey fuller test (ADF) was employed as test of stationary of the time series. The general form of ADF is estimated by the following regression;

$\Delta \mathrm{qt}=\lambda_{\theta+} \chi_{1} \mathrm{q}_{\mathrm{t}-1}+\sum \lambda_{1} \Delta \mathrm{q}_{1}+\theta_{\mathrm{t}}+\mathrm{e}_{\mathrm{t}}$

Where:

$\mathrm{q}=$ time series

$\mathrm{t}=$ linear time trend

$\Delta=$ the first difference operator

$\lambda_{\theta}=$ constant

$\mathrm{t}-1=$ the optimum number of lags in the independent variable and

$\mathrm{e}=$ random error term.

Meanwhile, the Granger causality test shows the direction of effect between two time series. Such effect could be bilateral, bidirectional, unidirectional and independence causality. The general form of Granger causality is estimated by considering two variables GDP and MSC in the following regression:

$\mathrm{GDP}_{\mathrm{t}}=\sum_{\mathrm{t}=1} \mathrm{G}_{1} \mathrm{GDP}_{\mathrm{t}-1}+\sum \Omega \mathrm{MNCS}_{\mathrm{t}=1}+\mathrm{ElE}$

$\mathrm{MNCS}_{\mathrm{t}}=\sum_{\mathrm{t}=1} \mathrm{w}_{1} \mathrm{MNCS}_{\mathrm{t}-1}+\sum, \theta \mathrm{GDP}_{\mathrm{t}-1+\mathrm{E} 2 \mathrm{t}}$

Where it is assumed that the error term $\mathrm{e}_{1 \mathrm{t}}$ and $\mathrm{e}_{2 \mathrm{t}}$ are not correlated, the two variables case is called bilateral causality. Also, the GDP and MNCS in the equations, unidirectional causality from GDP to MNCS exists if the set of lagged MNCS coefficients in (II) is not statistically different form zero (i.e., $\sum_{w 1} \neq 0$ ) and the set of the lagged GDP coefficients in (III) is statistically different from (i.e., $\sum \theta 1 \neq 0$ ).

\section{Discussion of Results}

\begin{tabular}{|c|c|c|c|c|c|}
\hline \multirow{2}{*}{ Variables } & \multirow{2}{*}{ ADF Test } & \multicolumn{2}{|c|}{ Critical Value } & Order Integration & \multirow{2}{*}{ Order } \\
\cline { 3 - 5 } & & $\begin{array}{c}\mathbf{1 \%} \text { Critical } \\
\text { Value }\end{array}$ & $\begin{array}{c}\mathbf{5 \%} \text { Critical } \\
\text { Value }\end{array}$ & $\begin{array}{c}\text { 10\% Critical } \\
\text { Value }\end{array}$ & \\
\hline GDP & -7.263960 & -3.689194 & -2.971853 & -2.625121 & Order Two \\
\hline MCO & -4.918038 & -3.679322 & -2.967767 & -2.622989 & Order One \\
\hline MCA & -5.708008 & -3.679322 & -2.967767 & -2.622989 & Order One \\
\hline MNCs & -8.299966 & -3.679322 & -2.967767 & -2.622989 & Order One \\
\hline
\end{tabular}

Table 1: Unit Root Test for Stationary (Augmented Dickey Fuller)

Source: Author's Computation Using (E-Views 9.0)

The ADF unit root test of stationary test result presented in Table 1 show that all the variables used for the analysis were stationary at 1,5\% and $10 \%$ levels though none of the variables was stationary at level. In line with Granger and Newbold (1974), the non-stationary variables were differenced. Therefore GDP (economic growth) was stationary at order two. While, MCO (Multinational Corporation in oil sector), MCA (Multinational Corporation in Agricultural sector) and MNCs (Multinational Corporation in service sector) were all stationary at order one (first difference), this is because their respective ADF values were found to be greater than their critical values at $1 \%, 5 \%$ and $10 \%$. 


\begin{tabular}{|c|c|c|c|}
\hline Variables & OBS & F-Statistics & Prob \\
\hline $\mathrm{MCO} \longrightarrow \mathrm{GDP}$ & \multirow[t]{3}{*}{25} & \multirow[t]{2}{*}{3.30022} & \multirow[t]{2}{*}{0.0372} \\
\hline \multirow[t]{2}{*}{$\mathrm{GDP} \longrightarrow \mathrm{MCO}$} & & & \\
\hline & & 1.23104 & 0.3563 \\
\hline \multirow[t]{2}{*}{$\mathrm{MCA} \longrightarrow \mathrm{GDP}$} & \multirow[t]{3}{*}{25} & 4.28327 & 0.0154 \\
\hline & & 0.41869 & 0.8528 \\
\hline \multicolumn{3}{|l|}{$\mathrm{GDP} \longrightarrow \mathrm{MCA}$} & \\
\hline $\mathrm{MNCS} \longrightarrow \mathrm{GDP}$ & \multirow[t]{2}{*}{25} & 0.99554 & 0.4707 \\
\hline GDP $\longrightarrow$ MNCS & & 2.14606 & 0.1226 \\
\hline
\end{tabular}

Table 2: Granger Causality Test Results

Source: Author's Computation Using (E-Views 9.0)

In order to find out the direction of the effect of Multinational Corporation on economic growth, the pair wise Granger Causality Test was conducted. The result presented on Table 2 shows a unidirectional causality between the variables; Multinational corporation in oil sector and economic growth as well as multinational in Agricultural sector and economic growth. This further reveals that the variable multinational corporation in oil and Agricultural sectors impact on economic growth. The findings support the view of Odunlami and Awolusi (2015) that examined Multinational Corporation and economic development in Nigeria and found that multinational corporation impact on economic growth. Meanwhile, an independent causation occurs between Multinational Corporation in service sector and economic growth. It is therefore conclusion that multinational corporation in service sector does not impact on economic growth.

\section{Conclusion and Recommendations}

From the literature reviewed, it was discovered that most counties strive to attract the inflow of multinational companies due to the potential they have to improve the growth of the economy. Nigeria in quest for growth and development joined the rest of the world in seeking the inflow of multinational firms as it helps the domestic resource of the economy to enhanced economic growth. An augmented growth model was estimated via the Granger causality techniques to establish the relationship between the Multinational Corporation and economic growth (GDP). The variable were tested for stationary via ADF unit roof test and found to be stationary. Also, the Granger causality result shows that multinational corporation in oil and Agricultural sectors impact on economic growth, whiles multinational corporation in service sector does not impact on economic growth drivers and are crucial to Nigeria strive for development. But external variable such as technology transfer from multinational favors economic growth due to degree of openness. Thus, this study strongly supports innovation and Multinational Corporation as key drivers of economic growth in today's world economy and most especially in Nigeria.

Based on the findings of the study, the following recommendations were made: since Multinational Corporation in both oil and Agricultural sectors impact on economic growth of the Nigeria economy, there is the need for government to engage more of multinational firms in these sectors. Hence, government should re-strategize their standing policies and institutions, rather than merely attracting FDI, and should focus on effective transmission of technology. Similarly, policy makers should formulate and implement effective investment promotion policies through macroeconomic and institution frameworks, including stable and high economic growth rate, liberal exchange rates and compete corporate taxes rates.

\section{References}

i. Aworom, A. (2013). Multinational Corporation and Development in Nigeria. African Journal of Culture, Philosophy and Society 3(1), 62-67.

ii. Central Bank of Nigeria(2014).Statistical Bulletin. Lagos: CBN Publication.

iii. Eluka, J, Ndubuisi-okolo, P.U. \&Anekwe, R.I. (2016). Multinational corporation and their effect on Nigerian economy. European Journal of Business and management, 8(9).

iv. Granger, C. \&Newbold, P. (1974). Spurious regression in econometrics. Journal of Econometrics (2): 111-120.

v. NOTAP(2011). Publication, an agency under the aegis of the Federal Ministry of Science and Technology, Nigeria. (www.notap.gov.ng).

vi. Odunlami, S.A. \&Awolusi, O.D. (2015). Multinational Corporation and Economic Development in Nigeria. American Journal of Environment Policy and Management, 1(2): 16-24.

vii. Okon, U.O., Augustine, O.J. \&Chuku, A.C. (2012). Foreign Direct Investment and economic Growth in Nigeria. An analysis of the endogenous Effects.Current Research Journal of Economic Theory,4(3):53-66.

viii. Onodugo, V.A.(2013). Multinational Corporation and employment and Labor conditions of Developing countries: The Nigerian Experience. European Journal of Business and Social Science, 1(6): 67-76.

ix. Osagwwu, G.O. \&Ezie, O. (2013). Multinational Corporation and the Nigerian Economy. International Journal of Academic Research in Business and Social Science, 3(4).

x. Saibu, O. \&Keke, N.A. (2014). Real output Effects of foreign direct investment in Nigeria. Journal of Behavioral Economics, finance, Entrepreneurship, Accounting and Transport, 2 (1), 1-7. DOI: 10.12691/jbe-2-1-1

xi. Tejvane, P. (2013), New Trade Theory. London: John Wiley and Sons.

xii. Udensi, E.U (2015). The impacts of Multinational Corporation to the Nigerian Economy. Intentional Journal of Social Science and Humanities Research, 3(2); 107-115.

xiii. UNCTAD (2000). Capital flows and growth in Africa. UNCTAD/GDS/MDPB/7, New York and Geneva: United Nations. 